\section{Plants of the Scottish Lower Carboniferous}

Transactions of the Royal Society of Edinburgh, 66, No. 1: "On the Structure of Some Petioles Associated with Rhetinangium Gordon" represents one of a sories by Mr. A. G. Long on the plants of the Scottish Lower Carboniferous (Pp. $8+2$ plates. Edinburgh: The Royal Society of Edinburgh, 1964. 6s.). We formerly knew very little about plants of this age, but now, thanks as much to Long as anyone, we have something like half knowledge of a considerable number, and very strange some of these plants are. In this paper, Mr. Long describes some petioles and petiole branches as a new species, but he thinks they belong to the stem Rhetinangium doscribed fifty years ago. What is perhaps of more significance, he finds that the peculiar seeds Genomosperma are repeatedly associated with the potiole fragments. Thus, something approaching a whole plant begins to emerge, though still obscure and indeed insecure. Even such a synthesis is very remarkable with the infrequent and scattered fragmonts that constitute this flora.

\section{Orientation of Stone Monuments and Buildings of Antiquity in the Near East}

RECENTLY it has been suggested that many of the great stone monuments and buildings of antiquity were erected as calendars, being carefully orientated in respect to the Moon or some other heavenly body. A study of certain Ziggurats by G. Charrière, in the near east, would appear to confirm this suggestion (Revue D'Assyriologie et Archéologie Orientale, 'L'Orientation de Quelques Ziggurats et Sanctuaires du Moyen-Orient" RA 58-1964). The article in question gives a detailed account of a number of examples such as the Moon palace of Sargon, the Ziggurat of Ur and certain Egyptian sanctuaries. Among an agricultural people the relationship between the calendar and religion is necessarily close, and this is often reflected in the orientation of their monuments.

\section{Perkin Centenary Awards, 1965-1966}

Applications for the award of Perkin Centenary scholarships are invited by the Perkin Centenary Trust. Awards, tenable for one or two years and renewable for a further year at the discretion of the Trustees, are offered to candidates employed in an industrial firm or other institution concerned with the manufacture or the application of colouring matter, for study at a university or technical college. Two types of award are available, some to the value of $£ 100$, which are to be used in conjunction with a local education authority grant, and others to a value of $£ 400$, which are intended for students whose normal grant, inclusive of fees, would be less than about $£ 300$. Perkin travel grants are also available to teachers concerned with the study of any aspect of the manufacture or the application of colouring matter. Applications for the scholarships must be made by May 1, 1965, and for the travel grants by December 1, 1964. Further information can be obtained from the Secretary, Perkin Centenary Trust, c/o The Chemical Society, Burlington House, London, W.1.

\section{The Night Sky in November}

New moon occurs on Nov. $4 \mathrm{~d} 07 \mathrm{~h} 17 \mathrm{~m}$ U.T. and full moon on Nov. $19 \mathrm{~d} 15 \mathrm{~h} 43 \mathrm{~m}$. The following conjunctions with the Moon occur: Nov. $13 \mathrm{~d} 02 \mathrm{~h}$, Saturn $3^{\circ} \mathrm{N}$.; Nov. $19 \mathrm{~d} 04 \mathrm{~h}$, Jupiter $2^{\circ} \mathrm{N}$.; Nov. 26d $16 \mathrm{~h}$, Mars $3^{\circ} \mathrm{S}$. Mars is in conjunction with Regulus on Nov. $4 \mathrm{~d} 0 \mathrm{lh}$, Mars being $1 \cdot 3^{\circ}$ N., Mercury with Antares on Nov. 14d $12 \mathrm{~h}$, Mercury being $2^{\circ} \mathrm{N}$, and Venus with Spica on Nov. $18 \mathrm{~d} 08 \mathrm{~h}$, Venus being $4^{\circ} \mathrm{N}$. Mercury is too close to the Sun for observation. Venus is a morning star, rising at $3 \mathrm{~h} 15 \mathrm{~m}$, $3 \mathrm{~h} 55 \mathrm{~m}$ and $4 \mathrm{~h} 45 \mathrm{~m}$ on November 1,15 and 30 , respectively. Its stellar magnitude is -3.5 ; its distance from the Earth increases during the month from 108 to 125 million miles and the visible portion of the apparent disk from 0.765 to $0 \cdot 848$. Mars rises at $0 \mathrm{~h} 05 \mathrm{~m}, 23 \mathrm{~h} 50 \mathrm{~m}$ and $23 \mathrm{~h} 30 \mathrm{~m}$ at the beginning, middle and end of the month, respectively. Its stellar magnitude is $+1 \cdot 2$ and its distance from the Earth on November 15 is 140 million miles. Mars is in Leo throughout the month. Jupiter is above the horizon virtually all night, rising at sunset on Novem. ber 12. Its motion is now retrograde near the boundary between Taurus and Aries, it is in opposition on November 13 , its stellar magnitude is $-\mathbf{2 \cdot 4}$, and its distance from the Earth at opposition is 372 million miles. Saturn sets at $0 \mathrm{~h} 15 \mathrm{~m}, 23 \mathrm{~h} 20 \mathrm{~m}$ and $22 \mathrm{~h} 20 \mathrm{~m}$ on November 1,15 and 30 , respectively. It is stationary in Aquarius on November 2 , after which it resumes its eastwards motion among the stars. Its stellar magnitude is +1.0 and its distance from the Earth on November 15 is 895 million miles. Occultations by the Moon of stars brighter than magnitude 6 are as follows, observations being made at Greenwich: Nov. 9d $16 \mathrm{~h} 46.9 \mathrm{~m}$, \& Sgr. m. $(D)$; Nov. $18 \mathrm{~d} 01 \mathrm{~h} 41 \cdot 2 \mathrm{~m}$, हु Cet. $(D)$; Nov. $20 \mathrm{~d} 2 \mathrm{lh} 53.0 \mathrm{~m}$, ‘ Tau. $(R)$; Nov. $21 \mathrm{~d} 05 \mathrm{~h}$ $21.5 \mathrm{~m}, 109$ Tau. $(R)$; Nov. $21 \mathrm{~d} 19 \mathrm{~h} 20.6 \mathrm{~m}, 1 \mathrm{Gem} .(D)$; Nov. $21 \mathrm{~d} 20 \mathrm{~h} 11 \cdot 0 \mathrm{~m}, 1 \mathrm{Gem}$. $(R)$. An occultation by Mars of $B . D .+19^{\circ} 1559$ (mag. 7.4) has been predicted, Nov. 23d $03 \mathrm{~h} 36 \mathrm{~m}(D)$, Nov. 23d 03h $4 \operatorname{lm}(R)$. $D$ and $R$ refer to disappearance and roappearance, respectively. The Taurid metoors are active during October 26-November 16, with maximum between November 1 and November 9 . The radiant is near R.A. $3 \mathrm{~h} 36 \mathrm{~m}$, Dec. $+14^{\circ}$, and con. ditions for observation are favourable. The Leonid meteors are active during November 14-17, with maximum on November 16. The radiant is near R.A. $10 \mathrm{~h} 08 \mathrm{~m}$, Dec. $+22^{\circ}$, and conditions for observation are favourable.

\section{Announcements}

Prof. M. G. Kendall has been elected president of the Institute of Statisticians in succession to the late Lord Bevoridge, who was founder president of the Institute. Mr. R. Brech, formerly honorary secretary, has been elected chairman in succession to Prof. G. A. Barnard. who retired at the end of his term of office. Mr. F. D. K. Liddell has been elected honorary secretary.

Mr. AUSTIN BouRke, assistant director of the Irish Meteorological Service, has been appointed director of the Irish Meteorological Service in succession to the late Dr. M. Doporto (see p. 329 of this issue of Nature). Mr. Bourke is at present vice-president of the International Society of Biometeorology.

A symposium on pulse radiolysis will be held in Manchester, jointly by the Department of Chemistry of thr University and the Paterson Laboratories, Christie Hospital and Holt Radium Institute, during April 21-23, 1965, immediately preceding the Miller Conference. Further information can be obtained from Dr. M. Ebert, Paterson Laboratories, Christie Hospital and Holt Radium Institute, Withington, Manchester 20.

THe following Acorn Meetings are to be held at the Arthur D. Little Research Institute: "The Interaction of Slow Electrons with Molecules" (November 16); "Organometallic Research in Industry" (December 7); "The Sleoping Brain" (January 11, 1965); "Solar Radiation-A Meteorological Cinderella" (Fobruary 8, 1965); "The Matchbox Pole-balancer-A Computer Programme which Learns by Trial and Error" (March 22, 1965). Further information can be obtained from Dr. R. E. Lister, Arthur D. Little Research Institute, Inveresk Gate, Musselburgh, Edinburgh.

Corrigendum. In criticizing the illustrations in Animul Worlds, by Marston Bates (Nature, 203, 907; 1964), Dr. L. Harrison Matthews stated that a photograph labelled "living zoo-plankton" is manifestly a preserved dead sample. The sample was, in fact, merely narcotized and was thus still living. 